Lev Fishman ${ }^{1}$

Russian Federation, Samara State Academy of Social Sciences and Humanities, School of Economics, Management and Service
ORIGINAL SCIENTIFIC ARTICLE doi:10.5937/ekonomika1503001F

Received: July 2, 2015 Accepted: August 31, 2015

\title{
FACULTY CULTURE AT A RUSSIAN PROVINCIAL UNIVERSITY: AN EMPIRICAL STUDY
}

\begin{abstract}
The paper presents the results of the empirical study of faculty culture at a Russian provincial university. This research study examines faculty attitudes toward implementation of the new State Higher Education standards. A survey was conducted among a majority of faculty members. We also interviewed representatives of the university administration and the administration of its schools. We identified three groups of professors with different views on changes required, proved, that implementation of new educational standards strongly depends on Chairs'leadership and that the ability to articulate educational outcomes is a professor's core competence.
\end{abstract}

Key words: organizational culture, corporate culture, culture of faculty.

JEL classification: I23 Higher Education

\section{ФАКУЛТЕТСКА КУЛТУРА НА РУСКОМ ПОКРАЈИНСКОМ УНИВЕРЗИТЕТУ: ЕМПИРИЈСКА СТУДИЈА}

\begin{abstract}
Апстракт
У раду су приказани резултати емпиријског истраживања културе факултета руског покрајинског универзитета. Ово истраживање испитује ставове факултета о имплементацији нових стандарда високог образовања. Истраживање је спроведено међу већином чланова факултета. Такође, интервјуисани су представници универзитетске управе и администрације. Идентификовали смо три групе професора са различитим ставовима о потребним променама и доказали је да примена нових образовних стандарда у великој мери зависи од руководства и да је суштинска способност професора заправо да артикулишу образовне исходе.
\end{abstract}

Кључне речи: организациона култура, корпоративна култура, култура факултета.

\footnotetext{
${ }^{1} 1$ fishman@mail.ru
} 


\section{Introduction}

Organizational culture, how to study it and how to change it have been in the focus of attention of various scholars for several decades. Many of these publications focus on the peculiarities of organizational cultures of specific economic sectors. The majority of these "sectorial" publications in Russia are devoted to university organizational culture. This situation can be explained by the fact that the majority of researchers work in universities.

The analysis of publications (mostly Russian ones) devoted to the conceptualization, study and change of the organizational culture of universities, shows that the majority of these publications are purely theoretical and do not include any empirical research. This may be due to significant difficulties both in the object of such research and the complexity of such empirical research itself.

However, nearly all Russian publications of the last decade point to the low quality of Russian university education, an unwillingness to respond to a requirement for improving higher education, and some opposition by university faculty toward implementation of new State Higher Education standards1. This opposition has been manifested both in rejecting the practicality of this transition (visible resistance) and latent resistance, as manifested in the absence of changes in teaching.

This study, then, is an attempt to conduct empirical research on the organizational culture of a particular university, and of its main (faculty) subculture in particular, as revealed through professors' attitudes toward the implementation of Federal educational standards. An average provincial university (delivering principally humanitarian programs) was chosen as the object of this research. The administration of the university is strongly committed to implement these new educational standards.

\section{Research Design}

In our research, we relied on Schein's classical definition of organizational culture and his algorithm for deciphering organizational culture (Schein, 2002). We also employed Handy's organizational cultures typology (Handy, 1993) and the system of organizational culture assessment and diagnostics suggested by Cameron and Quinn (Cameron and Quinn, 2001).

Analysis of domestic publications, focused on the organizational culture of a university, shows that a vast majority of researchers mainly describes an ideal situation thus omitting reality from detailed study (Franc, 2006; Gorshkova, Mal'ceva, 2006; Tikhomirova, 2008; Grudzinski, Bednyi, 2009; Kozlov, 2009; Sokurenko 2010; Akimova, Franc, 2012; Grudzinski, Petrova, 2012) or study students' perceptions of a university (Kravcova, 2008). In fact, we can distinguish a separate type of corporate culture - the corporate culture of a university. This corporate culture represents the basic values, preferences and norms defining the behaviour of faculty, staff and students, provides for constructive interaction on the team of a university, and contributes to realizing the State's requirements for education (Tarabaeyva, 2008), though there are questions about whether this interaction is constructive in every university and whether it really contributes to the implementation of the requirements in question. 
It is commonplace that everyone wishes corporate university culture would be an inseparable part of these organizations' life. This allows us to speak about a university as a self-organized system built on the principles of value of knowledge, and the freedom of teaching and learning. These values are a specific way to achieve the idea of a university (Yablonskene, 2006), but it is clear that the real lives of students and teachers of many domestic universities are built on entirely different principles.

Many authors (e.g., Hanevich, 2009) propose a set of values for educational activity shared by the majority of faculty, namely: competence, professionalism, responsibility, the value of higher education, love of the profession, citizenship, patriotism and tolerance of faculty. But these publications hardly help us to understand the real organizational culture of a particular university and the reasons for the resistance of professors (sometimes in great numbers) to changes.

At the same time empirical research from even the past 10 years shows that the organizational culture of an "average" Russian university is often hierarchical, and tends towards a family (clan) kind of culture; this reflects, in line with the prevailing mentality, an orientation to State paternalism (Makarkin, Tomilin, Britov, 2004). It is very unlikely that the situation in most universities could have seriously changed for the better in recent years. It is clear to any impartial observer that organizational culture in many Russian universities (for objective reasons) is still traditional, "late Soviet" (Kremneva, 2007); this becomes the main source of resistance to the required accommodation to this new environment.

That is why we intended to study certain aspects of the existing organizational culture of a "regular" Russian university. We had two principal alternatives for consideration of the corporate culture (culture as what an organization has, and as what it is (Yablonskene, 2006)). But being specifically interested in the behavioural norms, rituals, traditions, etc. that correspond to the values shared by faculty (Yablonskene 2006), we chose the first option.

It is understandable enough that the empirical study, we undertook could only use methods described by Schein as "other sources of culturological information" (Schein, 2002). According to Schein, the main ways and means of approaching such a study (expert participation, group meetings, identification of cultural influences, etc.) assume the initiative and participation of a university administration. We actually used a survey of a substantial number of university professors (the subculture of faculty, which, from our point of view, is the core of the corporate culture of a university); the author also interviewed a small number of senior (rectorate) and secondary (dean-level) administration. In the first case, we examined the views and attitudes of the faculty, and in the second, we studied other sources of cultural information: organizational structure and information, control and reward systems (Schein, 2002).

We clearly understood the complexity of studying culture by means of a survey. In particular, we realized that culture is multi-dimensional, but at the same time we could not afford to use an extensive (bulky) questionnaire. We recognized that different components of culture had different significance for group activity, and therefore the professors' views and attitudes selected for study characterized the researcher's view about it and not the culture itself. Finally, we were well aware that the respondents were likely only partially truthful in their answers. Moreover, we were convinced that because of a respondent' wish to guess which answers would be seen as "desirable" by 
the university administration, the interpretation of the data should only be qualitative and not quantitative.

The following aspects of the views, attitudes, values of the faculty reflected and manifested in the corporate culture of the university were chosen for study.

The first unit includes faculty members' relationships with students: the degree of a professor's dominance in the relationship with students (the degree of a professor's respect toward students), and a professor's perception of the marks he or she gives to students (whether a professor tries to guide a student to further effective learning with the help of assessment).

The second unit dealt with a professor's relationships with colleagues in the department and the relationship with the immediate superior (Department Chair): how important for the group a professor considers him/herself, the way he or she evaluates his/ her participation in joint activities and discussions of working issues with colleagues, his (her) attitude to the Chair as a leader, the way a professor evaluates a Chair's attitude to himself (herself), the way a professor assesses the exactingness of the immediate superior.

Finally, in the third block, we studied attitude toward the job and changes in the job: the level of interest in the work, a professor's assessment of the Department's activity in implementing the new educational standards, attitude toward planning clear educational outcomes (required as a part of the implementation of those standards), attitude to the idea that in new conditions the main result of a professor's work is students' readiness for professional activity (and not a specific set of knowledge; this is the major component of the transition to the new standards), attitude to the module-rating system in students' evaluation2 (university administration is implementing this system as a technological component of the substantive transition to the new standards). It was assumed from the very beginning that the attitudes and relationships included in this block would be the most essential for studies of the faculty culture of the university and for determining its subcultures. This is because the variables included here characterize changes in activity: the existing organizational culture shows itself most distinctly in conflict with the changes being implemented.

It should be noted that we did not study the views of the faculty on research activities (the most important in terms of the "ideal" university). We believe it would be superfluous for a regular Russian provincial humanitarian university: it is well known that the existing attitude of the majority of professors toward research differs greatly from a "real" one. The second reason for not studying these aspects of the views, attitudes and values of faculty is the desire not to overload the survey instrument: we believed that doing so would lead to a noticeable decrease in the accuracy of answers. In other words, we had to sacrifice studying some parts of faculty perceptions and attitudes (the ones we considered the most obvious) in order to achieve more accuracy in other parts.

The questionnaire compiled consists of 12 substantial questions and 8 questions defining the professional-demographic characteristics of the respondents. The questionnaire was pilot tested with representatives of one of the Departments (those in the pilot test did not participate in the further poll) and was slightly adjusted after the test. More than half of the faculty of the University (224 out of 412 professors) took part in the survey, conducted on the initiative of the university administration. Professors (willing to participate in the survey) filled out the electronic form of the questionnaire. Heads of Departments were not invited to participate. 
In-depth interviewing of some representatives of the Rector's office and Deans' offices provided for evaluation of the above-mentioned views and attitudes of faculty, but also included (as mentioned above) some questions aimed at the study of certain aspects of organizational structure, as well as the systems of information, monitoring and reward.

\section{Analysis of Empirical Data}

\section{The overall picture}

When we examine the overall picture of the views and attitudes of faculty of the university (for obvious reasons we are concealing its identity), we should first of all note their uniformity on most of the questions in the questionnaire. However, there are issues on which opinions differ.

All but one of the professors interviewed state their work is "very interesting" (in most cases) or "generally interesting".

The absolute majority of respondents claim that their "colleagues respect them and consider them to be important members of the team", but $50 \%$ of the respondents are somewhat uncertain, choosing the option "more like yes". However, about $5 \%$ of faculty chose "more like no".

The set of questions about the relationship to one's immediate superior (Department Chair) did not generate a large divergence of views. Ninety-five percent of respondents believe that their "Chair is the real leader of the team" and $75 \%$ state this confidently. Ninety-eight percent say with various degree of certainty that the Chair "appreciates them as professionals" and is "demanding in terms of performance of duties".

In general, questionnaire responses showed a careful and respectful attitude of faculty to students. Eighty-four percent of respondents claim that they "will listen to a student in a disputed situation and would reconsider their decision on the evaluation, if they realize that it has been erroneous"; however, only $1 \%$ of respondents "will not listen to a student and will not change the decision". Ninety-one percent of professors say that they would "respect a student's disagreement on research issue"; we should underline that none of the professors would actively oppose a student's disagreement.

All of the respondents are rather actively (by their own estimation) involved in joint activities with colleagues at the Department, and $64 \%$ of the respondents chose the option "always". Sixty-two percent of professors say with confidence that "the work of their department is fully focused on implementation of the new educational standards," but $4 \%$ do not think so and state that "this orientation is only formal".

Fifty-four percent of the respondents think that it is very important for a professor to plan the educational outcomes (what the students should be able to do, what sorts of problems they should be able to solve, etc.) that he or she should ensure; but $11 \%$ of them incline to the opinion that the only need is to specify what subject content they should deliver to their students to how many hours they will be given for this.

The question about a module-rating system of students' evaluation caused the most profound divergence of views. Only $26 \%$ of respondents believe that the implementation of this system "is really useful", while $36 \%$ of them say that this implementation "is not as important" or "there is no necessity for it". 
Respondents' views differed about one more question. Forty percent of respondents believe that the mission of a university education is to teach a student his future profession, that is to teach professional competencies 3 , while $7 \%$ of them think that the main task "is to provide deep theoretical knowledge", 53\% lean hesitatingly toward one or another point of view.

The average numeric values of respondents' answers on 12 substantial questions can be seen in table 1 (numerical scale from 1 to -1 is used).

Table 1. The average values of respondents'answers in numerical scale

\begin{tabular}{|l|c|}
\hline \multicolumn{1}{|c|}{ Number of Question and its subject } & Average Value \\
\hline 1. The degree of interest in the work & 0,816143 \\
\hline 2. The degree of respect from colleagues & 0,681614 \\
\hline 3. Leadership qualities of a Department Chair & 0,829596 \\
\hline 4. The degree of the Chair's respect for a professor & 0,79148 \\
\hline 5. a Chair's exactingness & 0,863229 \\
\hline 6. The degree of respectful attitude toward student's disagreement on assessment & 0,90583 \\
\hline $\begin{array}{l}\text { 7. The degree of respectful attitude toward student's disagreement on research } \\
\text { issue }\end{array}$ & 0,952915 \\
\hline $\begin{array}{l}\text { 8. The degree of respondents' involvement in joint activities with colleagues } \\
\text { at the Department }\end{array}$ & 0,76009 \\
\hline 9. The degree of focus of a Department activity on new educational standards & 0,766816 \\
\hline \begin{tabular}{l} 
10. The importance of precise planning of educational outcomes \\
\hline $\begin{array}{l}\text { 11. The importance of implementation of the module-rating system in } \\
\text { students' assessment }\end{array}$
\end{tabular} & 0,636771 \\
\hline $\begin{array}{l}\text { 12. The mission of a university education as teaching students to master } \\
\text { professional competencies }\end{array}$ & 0,204036 \\
\hline
\end{tabular}

We should state that the results of this survey characterize very positively the culture of the faculty of this university: for most items (perhaps except the last two, which, however, also have positive values), the average values of professors' views and relations are just about ideal. But it is necessary to take into account a possible distortion of real opinions of part of the faculty caused by their desire to guess what answers would be "preferred by" the university administration.

\section{Different professors}

A generally positive overall picture does not exclude the existence of several essentially distinct groups of professors4 among the university faculty. The cluster analysis we conducted allowed us to identify three groups within the total sample (values of cluster centers are shown in table 2). We suggested names for each cluster and we use these names below to describe the particulars of the views of the group representatives. 
Table 2. The value of the cluster centers

\begin{tabular}{|l|c|c|c|}
\hline Number of Question and its subject & Cluster 1 & Cluster 2 & Cluster 3 \\
\hline 1. The degree of interest in the work & 0,802083 & 0,817073 & 0,826923 \\
\hline 2. The degree of respect from colleagues & 0,687500 & 0,711382 & 0,605769 \\
\hline 3. Leadership qualities of a Department Chair & 0,677083 & 0,869919 & 0,875000 \\
\hline 4. The degree of the Chair's respect for a professor & 0,781250 & 0,792683 & 0,798077 \\
\hline 5. a Chair's exactingness & 0,812500 & 0,873984 & 0,884615 \\
\hline $\begin{array}{l}\text { 6. The degree of respectful attitude toward student's } \\
\text { disagreement on assessment }\end{array}$ & 0,916667 & 0,930894 & 0,836538 \\
\hline $\begin{array}{l}\text { 7. The degree of respectful attitude toward student's } \\
\text { disagreement on research issue }\end{array}$ & 0,947917 & 0,963415 & 0,932692 \\
\hline $\begin{array}{l}\text { 8. The degree of respondents' involvement in joint } \\
\text { activities with colleagues at the Department }\end{array}$ & 0,697917 & 0,813008 & 0,692308 \\
\hline $\begin{array}{l}\text { 9. The degree of focus of a Department activity on } \\
\text { new educational standards }\end{array}$ & 0,614583 & 0,829268 & 0,759615 \\
\hline $\begin{array}{l}\text { 10. The importance of precise planning of } \\
\text { educational outcomes }\end{array}$ & 0,333333 & 0,756098 & 0,634615 \\
\hline $\begin{array}{l}\text { 11. The importance of implementation of the } \\
\text { module-rating system in students' assessment }\end{array}$ & $-0,177083$ & 0,719512 & $-0,663462$ \\
\hline $\begin{array}{l}\text { 12. The mission of a university education } \\
\text { as teaching students to master professional } \\
\text { competencies }\end{array}$ & $-0,656250$ & 0,715447 & 0,798077 \\
\hline
\end{tabular}

\section{Cluster 1 - "Skeptics" (22\% of respondents).}

This cluster of faculty has rather a negative attitude towards changes in their work and the means for implementing these changes. The cluster representatives have an extremely negative attitude towards higher education reform, especially regarding the aspect of transition to the new educational standards.

We should note that these professors say less often that their Department is focused on new educational standards and tend to estimate the leadership qualities of their Chair as rather low.

We should note that this cluster includes half of the professors with the fourth academic degree5, and the size of this group is a little over a fifth of the respondents. For obvious reasons, these are the senior professors who have significant influence on the organizational culture of the University in general and at its deepest level (the basic views, convictions and beliefs of the collective) in particular. So we shouldn't underestimate the influence of this cluster on the culture of the University, although the cluster is not the largest.

The cluster also includes: one third of interviewed male professors; a third of professors at the age of 45-60; nearly a third of professors over the age of 60; half of the representatives of the School A6; nearly half of the School B; a third of School C; and almost one third of the professors who did not take University professional development programs during the last 5 years. 
Cluster 2 - "Progressive Professors" (54\% of respondents).

This cluster is characterized by the highest average scores for most substantial questions with particularly high values of answers to the last four questions on the relationship to change. Representatives of the cluster interact well with a Chair, they easily find understanding with students, are conscious of the need of implementing new standards and support the ways of implementing them.

It is important that this cluster is the largest one: it comprises more than half of all the respondents, which seems to be a very positive characteristic of the university faculty. This cluster embraces the majority (2/3) of interviewed professors aged 30 to 45 years and has fewer professors over age 60 than other clusters. The cluster includes $2 / 3$ of the faculty of Schools D and E.

Cluster 3 - "Observers" (24\% of respondents).

This cluster can be called the most controversial and interesting in terms of research. On the one hand, the representatives of this cluster support the objectives of the new educational standards and on the other hand, are sharply negative toward the module-rating system of assessing students outcomes, which, as stated above, is used in the university as a means of real (not declared) transition to the new standards. At the same time, the question of the module-rating system was the only one in the questionnaire related to the real work of a professor and his or her main responsibilities. We can assume that either the representatives of this group do not really wish to implement the new educational standards that they support in words, or they consider the approach used by the university administration to be ineffective. In our view, any of the assumptions justify the name of the cluster: a positive attitude towards the overall objectives of the change combined with unwillingness to implement it.

We should add that the cluster demonstrates a relatively worse attitude toward students and relatively low willingness to participate in joint activities with colleagues in the Department. It may be an indicator of low involvement in work (however, this index is about the same in the first cluster, whose representatives are skeptical about the purpose of change).

A very significant fact is that this cluster includes only one professor who has the fourth academic degree. The age structure of the cluster is also worth mentioning: one third of all the respondents are more than 60 years old and one third of those who are less than 30 years are represented in it. In other words the cluster contains a disproportionate number of both the youngest and the oldest professors. It also includes a disproportionate number of professors without the third or fourth degree. The cluster comprises half of the representatives of School F.

It may be noted that the distribution of faculties of different schools in clusters differs very substantially (see table 3 ).

This distribution reflects different cultural situations in the schools, the dominance of various subcultures in different schools which may reflect the personalities of Deans and Department Chairs, and on the weak influence of the Rector's Office on the culture of the faculty as a whole. 
Table 3. Distribution of Schools representatives in the clusters

\begin{tabular}{|c|c|c|c|}
\hline School & "Skeptics" & $\begin{array}{c}\text { "Progressive } \\
\text { Professors" }\end{array}$ & "Observers" \\
\hline $\mathrm{G}$ & $25 \%$ & $50 \%$ & $25 \%$ \\
\hline $\mathrm{A}$ & $50 \%$ & $25 \%$ & $25 \%$ \\
\hline $\mathrm{H}$ & $11 \%$ & $52 \%$ & $37 \%$ \\
\hline $\mathrm{F}$ & $27 \%$ & $28 \%$ & $45 \%$ \\
\hline $\mathrm{B}$ & $33 \%$ & $60 \%$ & $7 \%$ \\
\hline $\mathrm{E}$ & $0 \%$ & $72 \%$ & $28 \%$ \\
\hline $\mathrm{C}$ & $44 \%$ & $43 \%$ & $13 \%$ \\
\hline $\mathrm{D}$ & $20 \%$ & $70 \%$ & $10 \%$ \\
\hline $\mathrm{I}$ & $25 \%$ & $50 \%$ & $25 \%$ \\
\hline $\begin{array}{c}\text { University } \\
\text { Departments }\end{array}$ & $15 \%$ & $69 \%$ & $16 \%$ \\
\hline
\end{tabular}

\section{Cultural relationships}

How the different views and relations of the university faculty are related is of undoubted interest. Correlation analysis revealed the following ${ }^{7}$.

1. If a professor feels that colleagues regard him as an important member of the team and treat him with respect, he also states that his or her Chair appreciates him as a specialist.

2. If a professor says that his (her) Chair is a real leader of the team, he (she) is also sure that the Chair appreciates him as a specialist.

3. If a professor feels that his (her) Chair is a real leader of the team, he (she) also claims that the Chair is demanding in terms of duty performance.

4. If a professor believes the Chair values him (her) as a specialist, he or she also claims that the Chair is demanding in terms of duty performance.

5. If a professor believes that the Chair is a real leader of the team, he (she) also claims that his (her) Department' activity is focused on implementing the new educational standards.

6. If a professor feels that the Chair is demanding in terms of duty performance, he (she) also claims that his Department is focused on implementing the new educational standards.

7. The more confidently a professor says that colleagues regard him as an important member of the team, the more actively he or she is involved in joint activities with colleagues at the Department.

8. If a professor feels that it is important to plan educational outcomes and the level to which they should be mastered, he (she) also thinks that a modulerating system of students' assessment is really necessary.

9. If a professor feels that it is important to plan educational outcomes and the level to which they should be mastered, he (she) also thinks that the primary mission of a university education is teaching students to master professional competencies. 
The analysis of correlations diagram shows that central variables associated with many aspects of the work of a professor are the professor's perception of the degree of respect shown to him/her by colleagues, of leadership qualities of the Chair, of the degree of his or her Chair's respect, of the Chair's exactingness and of the importance of planning clear educational outcomes.

The interconnection of the answers to the four questions dealing with the relationship with colleagues and with the Chair are easily understandable. However, the direct correlation of answers to the question on the degree of orientation of the Department activity toward new educational standards with answers to questions about a Chair's leadership qualities and his (her) exactingness are of some interest. This may mean that professors estimate the leadership qualities and exactingness of the Chair first of all by the efforts he or she makes to implement the new educational standards. Professors see a Chair's desire to conduct effective changes, and this inspires respect that is undoubtedly positive both in cultural terms and in terms of the need to change traditional modes of activity. The fact that both interest in the work and participation in joint activities are positively correlated with respect from colleagues can also be considered positive characteristics of the culture of the university faculty.

There is also significance in the interconnection of answers to the question about the importance of planning educational outcomes with the answers to three other questions: change in the primary objective of a university education: the need to implement the module-rating system of students' assessment; and a professor's participation in joint activities with colleagues in the Department.

As for the first two correlations, they are quite understandable since the real activity of a professor in implementing new standards, as well as the development of training modules and rating cards, requires precise planning of educational outcomes. Moreover, these correlations confirm the long-standing hypothesis of the author of this article, that ability to clearly articulate expected educational outcomes (and to choose appropriate tools for assessment) is a core competence of any teacher (not just a university professor), and the level of development of this competence (which is generally low in Russian education) is the main indicator of a teacher's professionalism and the ultimate factor influencing his or her professional consciousness.

But the third correlation seems curious as it apparently reflects the efforts of the university administration towards implementing the new educational standards. In fact, the more actively a professor communicates with colleagues, the more confidently he/she says that it is important to plan precise educational outcomes. In other words, activities and communication at the Department level force professors to change the concept of teaching.

No less curious is the fact that answers to questions about the attitude toward students are separated from other faculty views and represent a separate area of professors' consciousness. The author of the study expected to find correlations here, as the educational process is implemented by means of communication with students. So the lack of correlations of answers to these questions with others seems sad, no matter whether it is caused by wrong hypothesis or by weaknesses of the culture of the university faculty.

Here are the findings of correlation analysis of substantial questions and professional and demographic characteristics of respondents. 
1. Females are a bit more actively involved in joint activities with colleagues at the Department.

2. A professor's interest in the work slightly increases with age.

3. Young professors have slightly more liberal attitudes to the students and are more positive toward the module-rating system.

4. An academic degree (especially the fourth one) gives a professor confidence that colleagues respect him (her) and consider an important member of the team, as well as that a Chair appreciates him as a specialist.

5. However the professors who do not have the third or fourth academic degree share to a greater extent the goal of implementing the new educational standards .

6. Professors, who have gone through university professional development programs during the last 5 years are more confident in the respectful attitude of colleagues and in their own importance for the team, and are more involved in joint activities with colleagues at the Department. They demonstrate a more positive attitude toward changes in university education, including the application of module-rating system to student assessment.

We should note here that professional development programs which the university administration conduct are very effective not only in terms of implementing new educational standards but also in changing the corporate culture.

\section{Administration Perspective}

Several representatives of Rector's and Deans' offices were interviewed in order to clarify the findings of the faculty survey and to explore other aspects of faculty corporate culture (subculture).

The majority of these administrative respondents noted structural problems of the University. The organization is rather large; the buildings of the university are located in different parts of the city, a fact which can't help influencing the commonality of culture. This is one of the reasons for the large number of subcultures, which significantly differ from each other. It is important to note that the Rector's Office does not specify or pronounce common values, so it is difficult to recognize them. This produces a situation where some people working in the same institution or even in the same department, perform the same functions differently, have different views of the same problem, aim at different objectives, engage different policies, and do not pay attention to the interests and concerns of other schools and the university as a whole.

This may be the main reason for the problem of communication that was mentioned by nearly all the administrators. It manifests itself in the way various Dean's offices and Departments interact with the university administration (Rector's Office) and with each other. There is no mutual understanding in many areas. Representatives of the Dean's offices note some isolation of the University Administration from the schools and departments. Moreover, many functionaries of the University Administration are said not to be interested in achieving university objectives and just want to get rid of excessive work.

All the administrators agreed that no destructive conflicts appeared in the interaction between faculty members. 
The administrators state that the majority of professors do not aim at demonstrating their superiority and domination in their relations with students On the other hand, the administrators point out that some professors do not want to build up a constructive relationship with the students and do not consider it important. They simply perceive students as material to work with while delivering lectures

Many administrators perceive the relationship between professors and students in different schools to be significantly different. Moreover, the students of different schools differ from each other, and this situation reflects very different cultural paradigms.

All the representatives of the administration consider the implementation of the new educational standards to be very "painful". A substantial part of faculty do not understand the necessity of it, while others face difficulties in doing this work. However, almost all the interviewed representatives of the Rector's and deans' offices do not see the situation as critical, because they understand that innovations and changes do cause resistance and professors have to significantly readjust to these changes both psychologically and culturally. So the administration has to find the means to overcome this resistance of the faculty.

Administrators think that traditional knowledge-based component of education remains the most important for the majority of professors, while the new educational standards declare competences as the main outcome of teaching-learning process. At the same time administrators see a significant change in the consciousness of professors. They are beginning to accept the new standards. Faculty development organized in the university and carried out regularly plays an important role here.

Administrators also identified key problems in the organization of the university's work, each of which contains a cultural dimension; they put forward some ideas for improving the culture. Among them are the following considerations:

- there is a need to improve the organizational structure; the existing structure is unconsolidated, which impedes the effectiveness of its functioning and makes internal interactions difficult.

- $\quad$ it is also necessary to change the process for assessing the subdivisions and specific administrative positions and to make assessment of performance more dependent on the results of activity.

- $\quad$ it is important to introduce new values and rules of behavior which would place students and professors (and not administration) in the focus of attention;

- there is a need to change HR policy, to focus on recruiting new strong leaders, to replace inefficient people in the Rector's office;

- a change in the organizational structure seems reasonable; it is necessary to consolidate some schools and departments as they are too small and do not provide appropriate results.

- radical change of the reward system is needed. Salary should depend on whether a professor achieves the actual goals and objectives of the university, not on his/her degree. 


\section{Conclusion}

Findings of the empirical research data analysis discussed above can be interpreted in different ways. The author has tried to do it as carefully as possible because he was aware that this study of faculty culture could be more deep. We also believe that the culture of faculty in different universities (provincial and humanitarian as well) may differ significantly.

But we can assume that for this university, as an institution engaged in education (we should remind the reader that faculty attitudes toward research activity have not been studied), "not all is lost". In fact, there are no serious conflicts between professors (as happens in a number of universities in the country), faculty relations with the chairs of departments and attitudes toward chairs are good enough. Professors are interested in their work; they are not hostile to implementing new standards, moderately resist necessary changes in activity. There is a feeling that university administration is truly oriented towards real changes (at least in teaching).

Yes, there are groups of professors with more negative attitude to the changes, who are not very willing to implement them. But they are the minority, and represent the older generation (the resistance of which should be stronger) and the youngest part (perhaps not yet socialized in the university).

At the same time, there is a feeling that the university administration does not use particular instruments of influence on corporate culture and, perhaps, on the situation in the university as a whole. And that particular finding may be typical in terms of its extension to many other universities. The existence of significant differences in the cultures of different schools suggests the critical dependence of professors' views, attitudes, and values on the personalities of the heads of schools and departments. Of course, this can be easily explained by the fact that these heads select the professors and constantly work with them. However, this may mean looseness in organizational structure, the lack of emphasis in the strategy (or the absence of strategy) where the activities of individual administrators and services are not fully focused on the new objectives, which results in a very high "degree of freedom" for middle level administration. Perhaps it is necessary to think about revising the Departmental system of universities, which comes into evident collision with new educational standards.

On the other hand, if the status and condition of schools and departments of a university inevitably depend on personalities of their heads, rectors may have to change their personnel policy. Candidates for these positions should be selected primarily based on their managerial competencies and not because they possess the highest academic degree, as most often happens today in provincial universities.

Finally, the reward system that exists in almost all universities in the country (in terms of salary for teaching hours) needs to be improved. Now, salary depends almost exclusively on the academic degree earned, and this can't help orienting the culture on clan or hierarchical patterns, which are not adapted to situations of change. 


\section{References}

Cameron K., Quinn R. (2001). Diagnosing and Changing Organizational Culture. St.Petersburg.

Handy C. (1993). Understanding Organizations. London, England; New York, N.Y., USA: Penguin Books.

Hanevich A. (2009). Hanevič A. P. Organizacionnaя kulstura vыsšego učebnogo zavedeniя v sovremennoй Rossii. Stavropolь.

Kremneva N. (2007). Kremneva N.Ю. Formirovanie korporativnoй kulьturы: Innovacii i stereotipы. Ulьяnovsk.

Makarkin N., Tomilin O., Britov A. (2004). Makarkin N.P., Tomilin O.B., Britov A.V. Rolь organizacionnoй kulьturы v эffektivnom menedžmente vыsšego učebnogo zavedeniя. Moskva.

Schein E. (2002). Organizational Culture and Leadership. St.-Petersburg.

Tarabaeyva V. (2008). Tarabaeva V.B. Ispolızovanie reguliruющih vozmožnosteй korporativnoй kulьturы v upravlenii konfliktami innovacionnogo razvitiя vuza. Belgorod.

Yablonskene N. (2006). Яblonskene N.L. Korporativnaя kulıtura sovremennogo universiteta. Moskva.

Grudzinski A., Bednyi A. (2009). Grudzinskiй A.O., Bednый A.В. Transfer znaniй funkciя innovacionnogo universiteta. Vыsšee obrazovanie v Rossii. 2009. №9.

Gorshkova O., Mal'ceva G. (2006). Gorškova O. V., Malıceva G.I. Rolь korporativnoй kulsturы v formirovanii эffektivnogo universiteta. Universitetskoe upravlenie: praktika i analiz. 2006. № 2. S.40 - 44.

Franc A. (2006). Franc A. S. Korporativnaя kulıtura universiteta (эtikoaksiologičeskiй aspekt). Universitetskoe upravlenie: praktika i analiz. - 2006. № 2. S. 26 - 30.

Kozlov M. (2009). Kozlov M.Ю. Socialьnые tehnologii upravleniя korporativnoй kulьturoй vыsšego učebnogo zavedeniя. Belgorod.

Akimova O., Franc O. (2012). Akimova O.B., Franc A.S. Korporativnaя kulbtura kak uslovie professionalıno-nravstvennogo razvitiя učastnikov obrazovatelınogo processa / Korporativnaя kulıtura obrazovatelьnыh uс̌reždeniй Ekaterinburg, 2012, s 8-12.

Kravcova J. (2008). Kravcova Ю.А. Metodы іzučeniя organizacionnoй kulıturы vыsših obrazovatelьnыh učreždeniй MVD Rossii. Voronež: Voronežskiй institut MVD Rossii. 2008.

Tikhomirova O. (2008). Tihomirova O.G. Organizacionnas kulstura: formirovanie, razvitie i ocenka. SPb.: Izd-vo Sankt-Peterburgskogo gosudarstvennogo universiteta informacionnыh tehnologiй, mehaniki i optiki.

Grudzinski A., Petrova O. (2012). Grudzinskiй A.O., Petrova O.V. Organizacionnaя kulıtura kak faktor razvitiя innovacionnogo universiteta // Vestnik Nižegorodskogo universiteta im. N.I. Lobačevskogo. - 2012. - №4(1). - S. 12 -17 . 
Sokurenko M. (2010) Sokurenko M.B. Realınaя i želaemaя modelı organizacionnoй kulsturы vuza v predstavlenii prepodavateleй i studentov // Эlektronnый žurnal PSYEDU.ru. 2010. №3. http://psyjournals.ru/authors/30629.shtml

\section{Acknowledgements:}

The author wishes to acknowledge Prof. Stephen Kerr, University of Washington, Seattle, WA USA, for helpful comments made on an earlier version of this article.

\section{Endnotes}

1 New State Higher Education standards in Russia describe educational outcomes in terms of professional skills or competencies as opposed to "pure academic knowledge" in the previous standards.

2 The module-rating system in students' evaluation requires precise planning of educational outcomes and the means of their evaluation.

3 This is one of the main ideas of new Russian education standards.

4 These groups may represent faculty subcultures of this university.

5 The Russian system of academic degrees differs from the Western: the PhD degree is split into Candidates (third degree) and Doctors (fourth degree).

6 We have obligation not to name the University and the Schools of the University.

7 Only statistically significant correlations were taken into account in compiling this list. 